\title{
Analysis and study of techniques for the development of the composition of fluxes for brass, bronze, and copper alloys
}

\author{
L.E.Yakubov ${ }^{1}$,N.N. Mamatkulov ${ }^{1}$ \\ ${ }^{1}$ Almalyk branch Tashkent State Technical University named after Islam Karimov, M. Ulugbek., 45, 110100,Almalyk, Uzbekistan. \\ E-mail: sohibtm@gmail.com
}

\begin{abstract}
This article provides the latest information on copper production processes. The research materialsfor obtaining copper and other alloys of nonferrous metals by scientists and developers are presented.

The development of a protective composition of flux for a charge with a large area has been introduced. And also, the design and properties of fluxes are given.

The article deals with casting alloys based on copper, brass, zinc. Their chemical composition, structure, casting, mechanical and operational properties, and application field are presented. The features of melting and production of shaped castings from casting alloys based on heavy nonferrous metals are considered.

This article describes methods for studying hydrogen content, quantitative indicators of waste of the charge, and brass shavings to determine gas porosity.

The article describes the development of a technology for heating a charge before loading it into a furnace for melting copper alloys in an induction furnace, an electric resistance furnace, and an electroslag furnace. The alloying element tin is a scarce and expensive element; therefore, tin bronzes produceessential parts.It also included developing a temperature regime for heating the charge before loading into a furnace for melting copper alloys in an induction furnace, an electric resistance furnace, and an electroslag furnace.
\end{abstract}

Key words: Fluxes, furnaces, alloy, melts, electrode, coke, copper, electric sludge, composition, charge, aluminum silicate.

\section{INTRODUCTION}

Fluxes, minerals added to the charge of metallurgical furnaces to obtain slags of specific chemical composition and required physical properties. The addition of flux is aimed at both lowering and increasing the melting temperature of the slag. Following the slags' nature, fluxes are usually divided into acidic and basic, less often alumina fluxes are used. In exceptional cases (for example, catastrophic failures), it is necessary to resort to highly effective fluxes, making it possible to obtain low-melting slags to quickly correct the furnaces' abnormal operationbizarre state of their refractory lining. Similar fluxes are also used systematically to obtain sufficiently liquid-melting (mobile), and, therefore, more active slags.
However, these cases are limited to the use of only minimal amounts of such intense fluxes.

In metallurgical processes for obtaining (and heating) ferrous metal (cast iron, iron, and steel), the following fluxes are usually used. Acidic fluxes (quartz, quartzite, quartz sand, broken siliceous, and siliceous bricks, broken red bricks) are used relatively rarely and in limited quantities.

At the same time, the technical, economic, and technological indicators of the whole process receive copper as a whole significantly increase [1].

Almost the same materials are used as a flux as in ferrous metallurgy. The most common fluxes: limestone, dolomite, iron ores, manganese ores, quartz, and aluminosilicates; Also, fluorspar, sulfides (for example, pyrite), gypsum, and barite are used as a flux. See above [2] for the influence of silicic materials and limestone on slag formation. Sulfides are used for sulfurization, that is, for the formation of matte, to avoid the transition of valuable metals into the slag in the case of ores containing little sulfur. Lime in nonferrous metals' metallurgy can be useful only in special conditions with high freight for fluxes. In lead smelting, lime (limestone) is introduced, replacing iron in slags according to the equation:

$$
\begin{aligned}
& 4 \mathrm{FeO} \cdot 2 \mathrm{SiO}_{2}+2 \mathrm{PbS}+2 \mathrm{CaO}+2 \mathrm{C}=2 \mathrm{~Pb}+2 \mathrm{FeS}+\left(2 \mathrm{CaO} \cdot \mathrm{SiO}_{2}+\right. \\
& \left.+2 \mathrm{FeO} \cdot \mathrm{SiO}_{2}\right)+2 \mathrm{CO}
\end{aligned}
$$

Besides, lime, being a robustnecessary flux, is capable of displacing most of the other bases from silicates, for example, by reaction:

$$
\mathrm{ZnO} \cdot \mathrm{SiO}_{2}+\mathrm{CaO}=\mathrm{CaO} \cdot \mathrm{SiO}_{2}+\mathrm{ZnO}(2)
$$

Iron ores are used for fluxes in the form of $\mathrm{FeO}$ and $\mathrm{Fe}_{2} \mathrm{O}_{3}$. Iron oxide $(\mathrm{FeO})$ is a very cheap slag component, forming liquid and low-melting slags, but increases the slag's specific gravity and the transition of $\mathrm{Cu}_{2} \mathrm{~S}$ into it. Ferrous flux is the basis for silicate ore:

$$
\mathrm{FeO} \cdot \mathrm{SiO}_{2}+\mathrm{FeO}=2 \mathrm{FeO} \cdot \mathrm{SiO}_{2}
$$

When reducing with carbon or carbon monoxide, iron oxides act as a precipitant for lead in the following reactions:

$$
\begin{aligned}
& 2 \mathrm{PbS}+4 \mathrm{FeO} \cdot \mathrm{SiO}_{2}+\mathrm{C}=2 \mathrm{~Pb}+2 \mathrm{FeS}+2 \mathrm{FeO} \cdot \mathrm{SiO}_{2}+\mathrm{CO}_{2} \\
& \text { or } \\
& 4 \mathrm{PbS}+2 \mathrm{Fe}_{2} \mathrm{O}_{3}+3 \mathrm{C}=4 \mathrm{~Pb}+4 \mathrm{FeS}+3 \mathrm{CO}_{2}
\end{aligned}
$$


The fluxing ability of iron ore is the higher, the cleaner the latter. The $\mathrm{SiO}_{2}$ present in the ore binds to part of the iron oxide and consumes a certain amount of $\mathrm{CaO}$ to form the corresponding slag. The following iron ores are used as a flux: hematite $\mathrm{Fe}_{2} \mathrm{O}_{3}$, limonite $\mathrm{Fe}_{2} \mathrm{O}_{3} \cdot \mathrm{nH}_{2} \mathrm{O}$, and, less often, siderite $\mathrm{FeCO}_{3}$. The practicality of using $\mathrm{Fe}_{3} \mathrm{O}_{4}$ (magnetic iron ore) in some cases is disputed, as sometimes it complicates the smelting process. Iron oxide $\left(\mathrm{Fe}_{2} \mathrm{O}_{3}\right)$ does not form silicates and slags with the latter's formation after reducingFeO. If $\mathrm{Fe}_{2} \mathrm{O}_{3}$ passes into slag without the drop, then the slag becomes thick. With bases, iron oxide forms heavy in specific gravity and very refractory ferrites, which affects the slag's properties. Manganese oxide $(\mathrm{MnO})$ is similar to iron oxide and replaces the latter in slags in equivalent amounts. Manganese oxides oxidize $\mathrm{ZnS}$ and reduce the slag's dissolving powerwith $\mathrm{ZnO}, \mathrm{MgO}$, and $\mathrm{BaS}$. Gypsum and barite give the sulfur necessary for the formation of matte, and at the same time, $\mathrm{CaO}$ and $\mathrm{BaO}$, which pass into the slag. Fluorspar melts at a temperature of $1378{ }^{\circ} \mathrm{C}$; it is very liquid when molten and dissolves the ore's refractory constituents. Currently, fluorspar is rarely used as a flux.

\section{METHODOLOGY}

To approximate the results obtained, we use the method of smoothing the experimental data using interpolation polynomials, which provides an updated value of Yi for a given value of Yi and a number of nearby values known with a random error [3]. In order to reduce random errors to a minimum, nonlinear smoothing was applied at seven points, which provide averaging based on the application of a thirddegree polynomial:

$$
\begin{gathered}
\mathrm{Y} 0=\left(39 \mathrm{Y} 0+8 \mathrm{Y} 1-4\left(\mathrm{Y}_{2}+\mathrm{Y}_{3}-\mathrm{Y}_{4}\right)+\mathrm{Y} 5-2 \mathrm{Y} 6\right) / 42 \\
\mathrm{Y} 1=(8 \mathrm{Y} 0+19 \mathrm{Y} 1+16 \mathrm{Y} 2+6 \mathrm{Y} 3-4 \mathrm{Y} 4-7 \mathrm{Y} 5+4 \mathrm{Y} 7) / 42 \\
\mathrm{Y} 2=(-4 \mathrm{Y} 0+16 \mathrm{Y} 1+19 \mathrm{Y} 2+12 \mathrm{Y} 3+2 \mathrm{Y} 4-4 \mathrm{Y} 5+\mathrm{Y} 6) / 42 \\
\mathrm{Yi}=(7 \mathrm{Yi}+6(\mathrm{Yi}+1+\mathrm{Yi}-1)+3(\mathrm{Yi}+2+\mathrm{Yi}-2)-2(\mathrm{Yi}+3+\mathrm{Yi}- \\
3)) / 21 \\
3<\mathrm{i}<\mathrm{N}-3 \\
\mathrm{Yn}-2=(\mathrm{Yn}-6-4 \mathrm{Yn}-5+2 \mathrm{Yn}-4+12 \mathrm{Yn}-3+19 \mathrm{Yn}-2+16 \mathrm{Yn}-1- \\
4 \mathrm{Yn}) / 42 \\
\mathrm{Yn}-1=(4 \mathrm{Yn}-6-7 \mathrm{Yn}-2+4 \mathrm{Yn}-4+6 \mathrm{Yn}-3+16 \mathrm{Yn}-2+19 \mathrm{n}-1 \\
+8 \mathrm{Yn}) / 42
\end{gathered}
$$

$$
\begin{gathered}
\mathrm{Yn}=(-2 \mathrm{Yn}-6+4 \mathrm{Yn}-5+\mathrm{Yn}-4-\mathrm{Yn}-3-4 \mathrm{Yn}-2+8 \mathrm{Yn}-1+ \\
39 \mathrm{Yn}) / 42
\end{gathered}
$$

Researchers of the Department of Foundry Technologies and Materials Science and Technology of New Materials of the Faculty of Mechanics of Tashkent State Technical University have developed a new method for electroslag remelting of easily oxidized charge [3]. When creating the process, we used the data of using an electroslag furnace for remelting steel with a consumable electrode. The distinctive principle of operation of this furnace is that it uses a non-consumable graphite electrode. A special protective flux is used as a slag, which reduces waste when melting an easily oxidized charge of nonferrous metals and alloys. With this remelting method, the quality of the obtained metal satisfies the physical and mechanical properties required by machine builders, while using a cheaper charge in production waste.

This article describes a unit for melting copper alloys by electroslag remelting. The research results determine fluxes' composition for melting copper alloys, including brass and bronze [5-7].

Experimental research on remelting was carried out on the installation shown in Figure 1. This installation is singlephase, powered by a welding transformer TS -500 . K - 50 was used as a measuring device, with which you can measure the current strength both on one electrode and on two or three, voltage, power.

The experimental setup (Figure 1) has a stand (1) along which the upper electrode (3) moves, a branch (2), a casing (4) $4 \mathrm{~mm}$ thick, which is connected to the pallet, a rammed lining (6), two stands (5), which hold the experimental setup and make it possible to rotate it by 1800 . At the bottom of the furnace is the lower electrode (10), isolated from the environment by a rammed lining. A copper hose (18) is led to the lower electrode. A copper hose (13), attached to an insulator (12) [8], is supplied to the upper electrode.

The presence of a movable upper electrode is because, with different slag, its electrical conductivity is different; therefore, it is necessary to change the current passage path carried out by this electrode. As the coke (7) heats up, slag (8) is added. After melting and tapping the metal, the installation is turned off and turned $180^{\circ}$, thereby removing the slag and coke. There are two rotary vaults in the unit's upper part, a hole (16) for a gas outlet. 

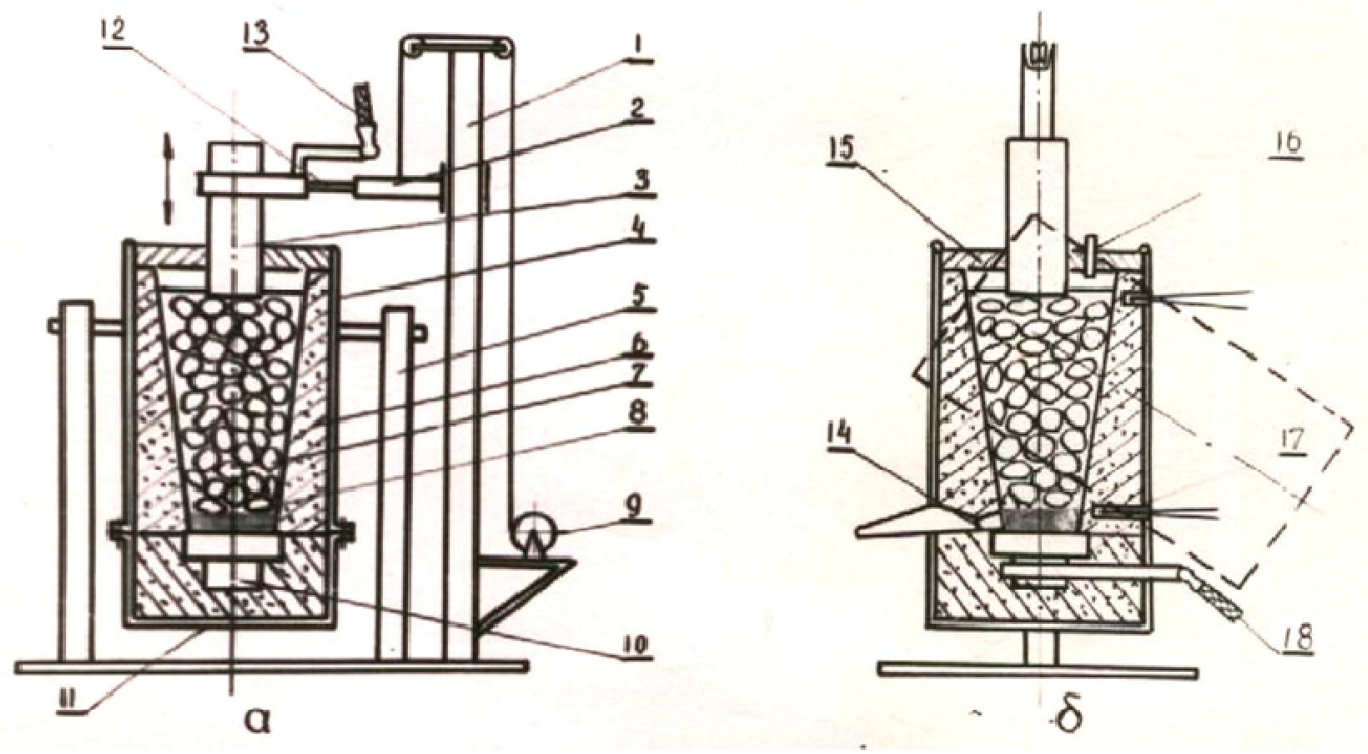

Figure 1.Diagram of a single-phase electroslag furnace

Since the coke's resistivity is high, the coke is heated under the passing current's influence and is brought to white heat. In this case, combustion products are formed on the coke; the coke burns only on the body, which leads to incomplete combustion [9].

As the coke heats up and burns along the surface, the filling level decreases, and the upper electrode is lowered below. After the coke has reached a sufficient temperature, the flux is filled from the corresponding components.

\section{OBJECTS AND RESEARCH METHODS}

Under the conditions of theCentral Repair and Mechanical Works (CRMW) of the Almalyk Mining and Metallurgical Combine, a technology of electroslag remelting of copper alloys that are different from the above schemes is proposed. The installation diagram is shown in Figure 2. This installation is single-phase, powered by a TS500 welding transformer. K-50 was used as a measuring device, with which you can measure the current strength both at one electrode and at two or three, voltage, power. This installation (Figure 4.1) has a stand (1) along which the upper electrode (3) moves, a branch (2), a casing (4) $4 \mathrm{~mm}$ thick, which is connected to the pallet, a stuffed lining (6), two stands (5), which hold the experimental setup and make it possible to rotate it by 1800 . At the bottom of the furnace is the lower electrode (10), isolated from the environment by a rammed lining. A copper hose (18) is connected to the lower electrode. A copper hose (13) attached to an insulator (12) is connected to the upper electrode.

As noted in the description, the presence of a movable upper electrode is because, with different slag, its electrical conductivity is different. Therefore, it is necessary to change the current flow path, which is carried out by this electrode. As the coke (7) heats up, slag (8) is added. After melting and tapping the metal, the installation is turned off and screwed to $180^{\circ}$, thereby removing slag and coke. There are two rotary vaults in the upper part of the unit, a hole (16) for a gas outlet [10].

Since the coke's resistivity is high, the coke is heated under the influence of the passing current and is brought to white heat. In this case, combustion products are formed on the coke; the coke burns only on the body, which leads to incomplete combustion. 

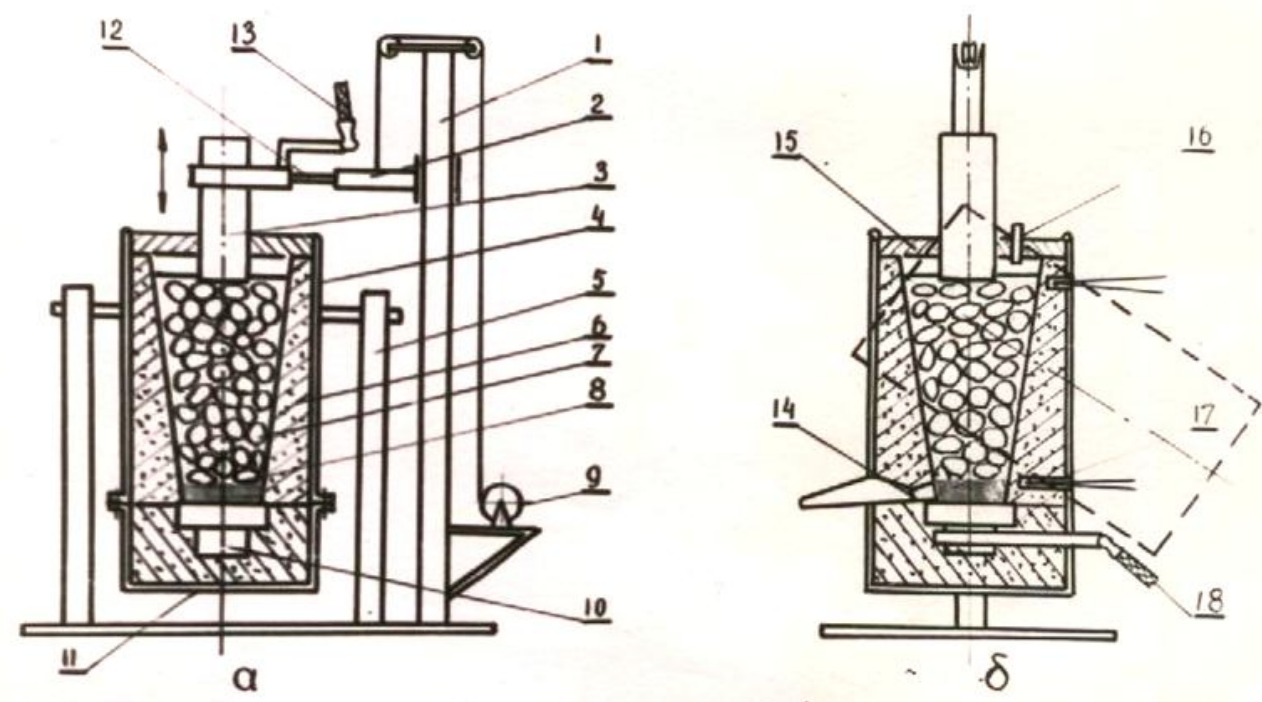

Figure 2.Diagram of an electroslag furnace

As the coke heats up and burns along the surface, the filling level decreases, and the upper electrode is lowered below. After the coke has reached a sufficient temperature, the flux is filled from the corresponding components.

The designer's supervision over the furnace's manufacture was carried out throughout the entire manufacturing period with a visit to the CRMW and the smelting shop of copper alloys. The control of the stove during manufacture was carried out with the chief welder's direct participation of the CRMW of the Almalyk Mining and Metallurgical Combine O.A.Reshetnikov. Some issues at the place of installation of the melting unit were resolved on-site based on safety requirements.

\section{RESULTS}

Determine the effect of the flux composition on the quantitative indicators of waste and saturation with gas inclusions. Studies of heats with a different piece of the flux were carried out. Table 1 and Table 2 show the characteristics of the most widely used types of melting furnaces for melting copper alloys and their comparative features.

Table1.Characteristics of the most widely used types of melting furnaces for melting copper alloys

\begin{tabular}{|c|c|c|c|c|c|c|c|c|}
\hline \multirow[b]{2}{*}{ № } & \multirow[b]{2}{*}{$\begin{array}{l}\text { Meltingunit } \\
\text { type }\end{array}$} & \multicolumn{5}{|c|}{ Characteristics of the melting unit } & \multicolumn{2}{|c|}{$\begin{array}{l}\text { Quantitative indicators of gas } \\
\text { inclusions in the melted alloys }\end{array}$} \\
\hline & & $\begin{array}{c}\text { Capacity- } \\
\text { bone, } t\end{array}$ & $\begin{array}{l}\text { Specific fuel } \\
\text { consumption }\end{array}$ & $\begin{array}{l}\text { Drivingcap } \\
\text { acity, } t / h\end{array}$ & $\begin{array}{l}\text { Waste of } \\
\text { metal,\% }\end{array}$ & $\begin{array}{c}\text { Efficiency } \\
\%\end{array}$ & $\begin{array}{l}\text { Gascontent, } \\
\mathrm{sm}^{3} / 100 \mathrm{~g}\end{array}$ & 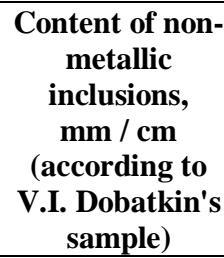 \\
\hline 1. & $\begin{array}{c}\text { Inductionchannel } \\
\text { furnaces }\end{array}$ & $0,4-16$ & $\begin{array}{c}520-453 \\
\text { KVth/t }\end{array}$ & $0,10-7$ & $1,6-2,0$ & $60-75$ & $0,4-1,2$ & $0,5-1,5$ \\
\hline 2. & $\begin{array}{l}\text { Inductioncrucibl } \\
\text { efurnaces }\end{array}$ & $0,4-10$ & $\begin{array}{c}727-557 \\
\text { KVth/t }\end{array}$ & $0,12-4,4$ & $2,0-2,3$ & 60 & $0,6-2,5$ & $0,9-2,7$ \\
\hline 3. & $\begin{array}{c}\text { Electricovens } \\
\text { Resistance } \\
\end{array}$ & $0,5-10$ & $\begin{array}{c}620-525 \\
\text { KVth/t } \\
\end{array}$ & $0,10-7$ & $1,6-1,8$ & $60-75$ & $0,4-1,2$ & $0,5-1,5$ \\
\hline 4. & $\begin{array}{c}\text { Electroslagfurna } \\
\text { ce }\end{array}$ & $0,2-1,2$ & $\begin{array}{c}40-1000 \\
\text { KVth/t }\end{array}$ & $0,2-1,2$ & $0.3-0,8$ & $75-80$ & $0,05-0,9$ & $0,08-0,12$ \\
\hline
\end{tabular}

The presented averaged data depend on the capacity, productivity, lining, quality of the charge, contamination, the state of the furnace, and the operating mode [11].

The use of electroslag furnaces for melting copper and, in particular, brass provides
- reduction of irrecoverable metal losses;

- saving energy costs;

- increasing labor productivity;

A significant increase in the melted melt's quality due to its passage through the flux layer. 
L.E.Yakubov et al., International Journal of Emerging Trends in Engineering Research, 8(10), October 2020, 6663 - 6669

The advantages of this Method:

1. The need for a second slag preparation unit is eliminated;

2. There is no need to make a consumable electrode;

3. Reduced waste when melting quickly oxidized charge;

4. By bridging the appropriate slag, you can remelt ferrous and nonferrous alloys;

5. With various slag compositions, alloys with different chemical compositions and properties can be obtained.
The use of alloy salts $(\mathrm{NaF}+\mathrm{NaCl})$ influxes leads to structure refinement and improves mechanical properties. Combine strength, wear-resistance, and enhanced heat dissipation, bimetallic castings are used [12].

Based on the experiments carried out on the developed electroslag furnace, results were obtained on determining the composition of the flux when melting copper alloys.

The composition of the flux used for refining copper alloys is shown in Table 2.

Table 2.The composition of the used flux for refining copper alloys

\begin{tabular}{|c|c|c|c|}
\hline № method & $\begin{array}{c}\text { Refiningmethods } \\
\text { (increasingdensity) }\end{array}$ & $\begin{array}{l}\text { Means for increasing the } \\
\text { purity and density of metal }\end{array}$ & Refiningtechnology \\
\hline 1. & \multirow{7}{*}{ Adsorption } & Titanium shavings & Mixing degreased chips for 5 minutes \\
\hline 2. & & Manganesechloride & Injection of $0.2 \% \mathrm{MnCl}_{2}$ in a bell \\
\hline 3. & & Hexochloroethane & Modification in three portions $(0.4 \%)$ in a bell \\
\hline 4. & & Argon & Purgefor 10 minutes \\
\hline 5. & & Universal flux & $\begin{array}{c}\text { Injection of } 2 \% \text { flux in the composition: } 50 \% \\
\mathrm{NaCl}, 30 \% \mathrm{NaF}, 10 \% \mathrm{Na}_{3} \mathrm{Al}_{6}, 10 \% \mathrm{KCl}, \\
\text { exposure for } 10 \text { minutes }\end{array}$ \\
\hline 6. & & Activefilter & $\begin{array}{l}\text { Filtration when pouring from the furnace into } \\
\text { the distributing crucible through a } 100 \mathrm{~mm} \\
\text { layer of flux composition: } 52.7 \%, 47.3 \% \mathrm{NaF}\end{array}$ \\
\hline 7. & & Inertfilter & Filtration through glass fabric SSFZ \\
\hline 8. & \multirow{2}{*}{ Non-adsorption } & Ultrasound & $\begin{array}{c}\text { Processing }(20 \mathrm{kHz}) \text { in } 2 \text { stages: first } 10 \\
\text { minutes, exposure } 10 \text { minutes; the second } 10 \\
\text { minutes }\end{array}$ \\
\hline 9. & & Vacuum & $\begin{array}{c}\text { Evacuation at } 10 \mathrm{~mm} \mathrm{Hg} \text { within } 15 \text { minutes } \\
\text { under a layer of flux in the composition: } 62 \% \\
13 \% 25 \% \text { ( } 0.2 \% \text { flux) }\end{array}$ \\
\hline 10. & Combinedrefining & $\begin{array}{l}\text { Filtration through an active } \\
\text { filter, then the evacuation }\end{array}$ & $e^{2}$ \\
\hline 11. & Crystallizationinautoclave & Pressure $0.5-0.6 \mathrm{MN} / \mathrm{m} 2-$ & - \\
\hline 12. & Electroslagremelting & $\begin{array}{l}\text { Melting, overheating in a layer } \\
\text { of liquid flux }\end{array}$ & $\begin{array}{c}\text { Various } \mathrm{NaCl}, \mathrm{KCl} \\
\mathrm{NaCl}+\mathrm{MnCl}+\mathrm{KCl} \\
\mathrm{NaCl}+\mathrm{NaF} \\
\mathrm{NaCl}+\mathrm{KCl}+\mathrm{NaFNaCl}+\mathrm{KCl}+\mathrm{NaF}\end{array}$ \\
\hline
\end{tabular}

Table 3 shows the main fluxes used for melting copper alloys.

Table3.The main fluxes used for melting copper alloys

\begin{tabular}{|c|c|c|c|c|c|c|c|c|}
\hline \multirow{2}{*}{ № } & \multirow{2}{*}{ Purposeoftheflux } & \multicolumn{7}{|c|}{ Flux components in weight percent } \\
\hline & & $\mathrm{NaCl}$ & $\mathrm{KCl}$ & $\mathrm{C}$ & $\mathrm{MgCl}_{2}$ & $\mathrm{CaCl}_{2}$ & $\mathrm{NaF}$ & $\mathrm{CaF}_{2}$ \\
\hline 1 & Forremeltingwaste & 50 & 30 & 20 & - & - & - & - \\
\hline 2 & Forremeltingwaste & 50 & 20 & 20 & - & 10 & - & - \\
\hline 3 & Forremeltingwaste & 40 & 20 & 8 & - & 2 & 30 & - \\
\hline 4 & Forremeltingwaste & 50 & 30 & 10 & - & - & - & 10 \\
\hline 5 & Forremeltingwaste & 50 & 45 & 15 & - & - & - & - \\
\hline 6 & Forremeltingwaste & 40 & 40 & 18 & - & - & 10 & - \\
\hline 7 & Coveringflux & 40 & - & 20 & 10 & 30 & - & - \\
\hline \multicolumn{9}{|c|}{ Heatsoffusion } \\
\hline 1 & $\begin{array}{c}\text { Specific heat of fusion, cal / } \\
\mathrm{g}\end{array}$ & 123,5 & 74,1 & - & 70 & 54,2 & 27,8 & - \\
\hline 2 & Meltingpoint, oC & 804,3 & 790 & 1330 & 712 & 772 & 962 & 577 \\
\hline 3 & Meltingpoint, oC & 2,163 & 189 & 3,18 & 2,32 & 2,152 & - & 1,85 \\
\hline
\end{tabular}

Determine the flux's optimal chemical composition for melting copper alloys; experimental melting was carried out in various furnaces [13].
The heats' results to determine the flux's optimal chemical composition for melting copper alloys, experimental melts were carried out in various furnaces, are 
L.E.Yakubov et al., International Journal of Emerging Trends in Engineering Research, 8(10), October 2020, 6663 - 6669

shown in table 4.

Table 4.The results of the melts to determine the optimal chemical composition of the flux for melting copper alloys, experimental melts were carried out in various furnaces

\begin{tabular}{|c|c|c|c|}
\hline № & $\begin{array}{c}\text { Furnace for melting copper } \\
\text { alloys }\end{array}$ & Fluxserialnumber & Wasteamount, \% \\
\hline 1 & \multirow{7}{*}{$\begin{array}{l}\text { Induction furnace with } \\
\text { preheated batch }\end{array}$} & 1 & $4-5$ \\
\hline 2 & & 2 & $4-5$ \\
\hline 3 & & 3 & $3-4$ \\
\hline 4 & & 4 & $3-4$ \\
\hline 5 & & 5 & $4-6$ \\
\hline 6 & & 6 & $4-5$ \\
\hline 7 & & 7 & $4-5$ \\
\hline 8 & \multirow{7}{*}{$\begin{array}{l}\text { Resistance furnace with } \\
\text { preheated charge }\end{array}$} & 1 & 6-7 \\
\hline 9 & & 2 & $4-5$ \\
\hline 10 & & 3 & $3-4$ \\
\hline 11 & & 4 & $3-4$ \\
\hline 12 & & 5 & $4-5$ \\
\hline 13 & & 6 & 4-6 \\
\hline 14 & & 7 & $4-6$ \\
\hline 15 & \multirow{7}{*}{$\begin{array}{l}\text { Electroslag furnace with } \\
\text { preliminary heating of the } \\
\text { charge }\end{array}$} & 1 & $2-3$ \\
\hline 16 & & 2 & $2-3$ \\
\hline 17 & & 3 & $2-3$ \\
\hline 18 & & 4 & $2-3$ \\
\hline 19 & & 5 & $2-3$ \\
\hline 20 & & 6 & $2-3$ \\
\hline 21 & & 7 & $2-3$ \\
\hline
\end{tabular}

According to the research results, it can be seen that the content of free carbon in the composition of the flux in an amount of $8-10 \%$ adequately protects the melt oxidation. The difference between smelting in an induction furnace and an electroslag furnace only becomes apparent when free carbon is used, apparently, due to the high temperature of overheating the melt in the arc burning zone. As you know, the activity of carbon to oxygen increases with increasing temperature. However, the exercise of copper alloys to oxygen also increases with increasing melt temperature. At the same time, the critical temperature for carbon is $18270 \mathrm{C}$. Above this mark, the activity of carbon sharply increases in comparison with copper alloys. It is this temperature that we have in the arc burning zone. Therefore, in an electroslag furnace, the effect of reducing waste is achieved in comparison with an induction furnace and a resistance furnace [14-15].

According to the results of experimental studies for melting copper alloys in an electroslag furnace, fluxes of the following composition are recommended (table 5)

Table 5.Composition of fluxes for melting copper alloys in an electroslag furnace

\begin{tabular}{|c|c|c|c|c|c|c|}
\hline \multirow{2}{*}{ Purposeoftheflux } & \multicolumn{5}{|c|}{ Flux components in weight percent } \\
\cline { 2 - 7 } & $\mathrm{NaCl}$ & $\mathrm{KCl}$ & $\mathrm{C}$ & $\mathrm{MgCl}_{2}$ & $\mathrm{CaCl}_{2}$ & $\mathrm{NaF}^{2}$ \\
\hline Forremeltingwaste & 50 & 30 & $8-10$ & 2 & $2-4$ & $5-6$ \\
\hline Forremeltingwaste & 50 & 20 & $8-10$ & 2 & $5-12$ & $3-4$ \\
\hline Forremeltingwaste & 40 & 40 & $8-10$ & 2 & 5 & 10 \\
\hline Coveringflux & 40 & 30 & $8-10$ & 5 & 5 & \\
\hline
\end{tabular}

\section{CONCLUSION}

Determine the effect of the flux composition on the quantitative indicators of waste and saturation with gas inclusions. Studies of heats with a different arrangement of the flux were carried out. The given averaged data depend on the capacity, productivity, lining, charge quality, contamination, furnace condition, and operating mode.

The use of electroslag furnaces for melting copper and, in particular, brass provides reduction of irrecoverable metal losses, savings in energy costs, increased labor productivity, a significant increase in the quality of the melted melt due to its passage through the flux layer.

\section{ACKNOWLEDGMENT}

The new composition of the flux for melting copper alloys was introduced at the central mechanical plant of JSC Almalyk MMC (certificate No. AYu-18-76 of JSC Almalyk MMC dated May 20, 2018). 


\section{REFERENCES}

1. Matkarimov S.T. et al., Hydrometallurgical Processing of Copper-Smelting Dust, International Journal of Emerging Trends in Engineering Research, 8(7), July 2020, 3088 - 3094 https://doi.org/10.30534/ijeter/2020/3587202

2. KupryakovYu.P. Slags from copper-smelting production and their processing. - M : Metallurgy, 1987 .p. 201.

3. Tarren W. ZahrasubersichtLeichtmetall - Sang and kokll - engub (19 Folge) teil 3. Schmelzen, Giepen, Technologie // Giesserei. - 1982.N13.pp.326-334.

4. Lidin RA, Molochko VA, Andreeva LL Reactions of inorganic substances: a reference book / Ed. R. A. Lidia. - 2nd ed., Rev. and add. -M .: Bustard, 2007 .-- S. 16.p.637 - ISBN 978-5-358-01303-2.

5. Shcherbatykh I, Carpenter DO (May 2007). The role of metals in Alzheimer's disease's etiology is (J. Alzheimer's Dis. 11 (2): pp.191-205.

6. Adler Yu.P., Markova E.V. Yu.V. GranovskyPlanning an experiment in the search for optimal conditions.-M.: Nauka, 1976.p.326

7. Kholikulov D.B et al.,Separation of metals from technological solutions copper production, International Journal of Emerging Trends in Engineering Research, 8(7), July 2020, 3557- 3561, ttps://doi.org/10.30534/ijeter/2020/110872020

8. Robertson I.L. Meltung of $\mathrm{Al} / /$ Metallurgis and Metal Forming. -1974.-N12.pp.357-361.

9. Vagi Ian Ichiro // 1. Mining and Met. Inst., Iap. 1977.-V. 93, N1077.pp.963-968.

10. Yakubov L.E., Turakhodzhaev N.D., TulyaganovE.Kh. Final report on contractual work No. 24 / 10-02-3865 / 10. Almalyk, 2012, p.112

11. Kurdyumov, A.V. Production of castings from nonferrous metal alloys / A.V. Kurdyumov [and others]. - M .: MISiS, 1996.

12. Shklyar M.S. Secondary nonferrous metallurgy furnaces. -M .: Metallurgy, 1987. p.216

13. Atkins R. Developments in metal melting and Holding in nonferrous foundries // Bereft. Foundryman. -1981.- 74, N8, XVI-XIX.pp.118131.

14. Tarren W. ZahrasubersichtLeichtmetall - Sang and kokll - engub (19 Folge) teil 3. Schmelzen, Giepen, Technologie // Giesserei. - 1982.N13.pp.326-334.

15. Matkarimov, S.T. et al, Technology of Deep Processing of Copper Slags by Method of Active Thermal Gravity. International Journal of Advanced Science and Technology, 29(03), 2020. 5633-5639. 